\section{God bok om endring av helseatferd}

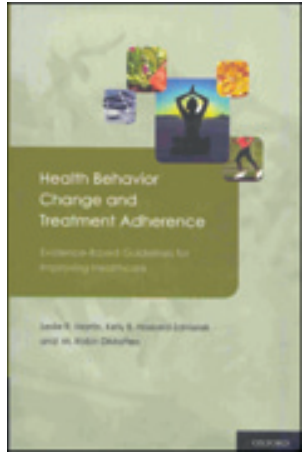

Leslie R. Martin, Kelly B. Haskard-Zolnierek,

M. Robin DiMatteo

Health behavior change

and treatment adherence

Evidence-based guidelines for improving healthcare. 212 s, tab, ill. Oxford: Oxford University Press, 2010. Pris GBP 19 ISBN 978-0-19-538040-8

Hvorfor er det så vanskelig å endre helseatferd og opprettholde gode helsevaner når atferden i seg selv ofte er svært enkel? Dette er kjernespørsmålet som forfatterne har stilt seg. Det finnes svært mye litteratur på området - fra vitenskapelige artikler til populærvitenskap. Forfatternes intensjon er å presentere et utvalg av nøkkelprinsipper for endring av helseatferd og de mest effektive strategiene som kan legge til rette for endring og fremme etterlevelse.

De argumenterer for en enkel tilnærming med en trekomponentmodell: informasjon, motivasjon og strategi. Før en person kan endre atferd må vedkommende vite hvilken endring som er nødvendig (informasjon), ønske endringen (motivasjon) samt ha og kunne bruke de redskaper som er nødvendige for å oppnå og vedlikeholde endringen (strategi). Mange kjenner godt til hva som bør gjøres og ønsker å endre sin atferd, men veldig få klarer å oppnå og vedlikeholde en gjennomført helsefremmende atferd over tid. Forfatterne belyser alle trinn i trekomponentmodellen, men legger spesiell vekt på forskjellige strategier for varig og helsefremmende atferdsendring tilpasset den enkelte pasient. De forskjellige teknikkene eksemplifiseres med relevante sykehistorier. Denne tilnærmingen kan implementeres i all medisinsk behandling som krever helsefremmende atferdsendring, f.eks. de fleste kroniske sykdommer, diabetes, fedme, rus, etc.

Boken er på 210 sider og inneholder enkelte oversiktstabeller, men ingen illustrasjoner. Den er inndelt $i$ åtte kapitler som presenterer ulike teoretiske forståelsesrammer for atferdsendring. Den er fortrinnsvis skrevet for leger og annet helsepersonell, men henvender seg også til lekfolk som aktivt ønsker å ta tak i egne levevaner og egen helseatferd.

Forfatterne lykkes godt med å beskrive og integrere ulike forståelsesrammer for endring av helseatferd. Velkjente teorier fra helsepsykologien er godt beskrevet og godt forklart med gode kliniske eksempler. En rekke helseatferdsmodeller har som utgangspunkt at vi mennesker er «rasjonelle aktører», men forfatterne evner å forklare kompleksiteten i helseatferd og endring av den. Innholdsmessig representerer denne utgivelsen mye mer enn oppramsing av teorier og forskningsresultater. Styrken ligger i selve fremstillingen av evidens - forfatterne evner å integrere teorier og modeller i en praktisk klinisk hverdag slik at det også blir forståelig for lekfolk. Slik å forstå kan Health behavior change and treatment adherence være retningsgivende for helsepersonell som ønsker å bistå pasientene med varig endring av levevanene.

Stadig flere overlever alvorlig sykdom, og flere rammes av kroniske sykdommer. I tillegg er overvekt og inaktivitet blant våre største helseutfordringer. Det er godt kjent at etterlevelsen av råd fra helsepersonell er lav ved en rekke livsstilssykdommer. Helsepersonell som kjenner til viktige prinsipper for atferdsendring og hvordan man kan integrere denne kunnskapen i pasientkonsultasjonen, har større muligheter for å hjelpe pasientene til varig endring av helseatferd. Denne utgivelsen er et viktig bidrag til å øke kunnskapen om helseatferd og, ikke minst, om hvordan man som helsepersonell kan forbedre den kliniske samtalen for å øke sannsynligheten for etterlevelse.

Det er begrenset hvor mange ulike perspektiver som kan presen- teres i en slik fremstilling, men vi synes at de motivasjonelle perspektivene burde inneholdt noe mer oppdatert kunnskap om selvbestemmelsesteori (self-determination theory). Denne teorien hevder at indre motivasjon handler om et dypt menneskelig behov for å være kompetent og selvbestemt i forhold til omgivelsene. Selvbestemmelse defineres som at personen tar sin egen vilje i bruk. Indre motivert er den som virkelig føler at aktiviteter og oppgaver er selvvalgte, at det er noe man innerst inne ønsker å drive med og at man er engasjert i dem med hele seg. Størst mulig grad av selvmonitorering er jo et mål i all behandling. Helseatferd som oppleves som selvbestemt, antas å ha større grad av varighet. I denne boken savner vi gode eksempler på hvordan helsepersonell kan støtte pasientens selvbestemmelse (autonomistøtte).

Vi anbefaler denne utgivelsen for helsepersonell som ønsker økt kunnskap om helseatferd og endring og for dem som ønsker praktiske råd for å forbedre pasientsamtalene og øke etterlevelsen. Om den er egnet for lekfolk, stiller vi oss noe mer tvilende til.

\section{Hege Gade}

Jøran Hjelmesæth

Senter for sykelig overvekt

Helse Sør-Øst

Sykehuset i Vestfold, Tønsberg

\section{Utmerket om kvinners røyking}

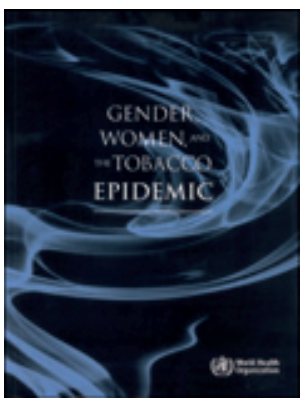

Verdens helseorganisasjon

Gender, women and the tobacco epidemic

249 s, tab, ill. Genève: WHO, 2010. Pris CHF 50 ISBN 978-92-4-159951-1

Menn er taperne i den globale sigarettepidemien. De startet å røyke på et tidligere historisk tidspunkt enn kvinner, de begynte tidligere i livsløpet og har hatt høyere sigarettkonsum per røyker. I Norge er eksempelvis mer enn $70 \%$ av all tobakk lagt ut for salg i tiden etter 1930 konsumert av menn. Globalt er røykeandelen $40 \%$ for menn og kun $9 \%$ for kvinner, og menn har dobbelt så høy risiko for å dø av en tobakksrelatert sykdom. Det kan derfor synes som et paradoks at WHO nå har utgitt en monografi med temaet kvinners røyking.

Årsaken er at andelen kvinner som røyker forventes å øke i de mest folkerike land i verden, at kvinner har forhøyet risiko for flere av de tobakksrelaterte sykdommene som rammer begge kjønn, samt at kvinner også har unike røykesykdommer. I tillegg er kvinner mest eksponert for passiv røyking. Det er dessuten knyttet spesifikke forhold til kvinnerøykingens oppstart, opprettholdelse og avslutning, noe som har betydning for utforming av tobakkspreventive programmer.

I fire deler tar man opp kvinnerøykingens helsekonsekvenser, utbredelse/bruksområder, opphør og implikasjoner for forebyggingsstrategier. En eminent ekspertgruppe har forfattet en nyttig oversikt som passer for et bredt spekter av folkehelsearbeidere. Den inneholder oppdatert statistikk, har et solid referanseverk og er et godt oppslagsverk. Kapitlenes hovedbudskap er gjennomgående løftet frem med stor skrift i margen og inviterer til effektiv kunnskapsoverlevering.

Karl Erik Lund

Statens institutt for rusmiddelforskning 